Document downloaded from:

http://hdl.handle.net/10251/46954

This paper must be cited as:

Barat Baviera, R.; Serralta Sevilla, J.; Ruano García, MV.; Jiménez Douglas, E.; Ribes Bertomeu, J.; Seco Torrecillas, A.; Ferrer, J. (2013). Biological Nutrient Removal Model № 2 (BNRM2): A general model for Wastewater Treatment Plants. Water Science and Technology. 67(7):1481-1489. doi:10.2166/wst.2013.004.

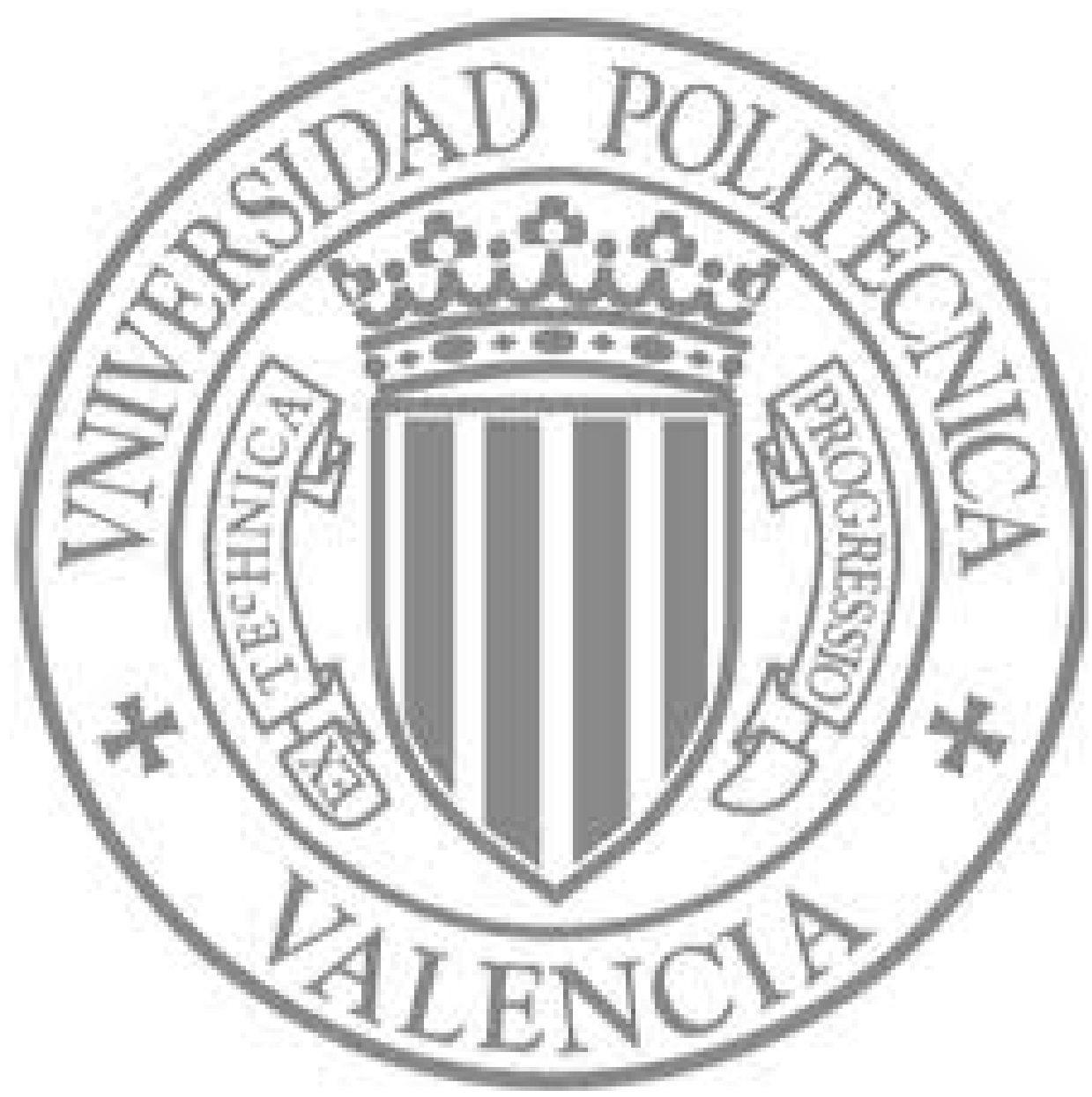

The final publication is available at

http://dx.doi.org/10.2166/wst.2013.004

Copyright IWA Publishing 


\title{
Biological Nutrient Removal Model No 2 (BNRM2): A general model for Wastewater Treatment Plants
}

\author{
R. Barat ${ }^{1}$, J. Serralta ${ }^{1}$, M.V. Ruano ${ }^{2}$, E. Jiménez ${ }^{1}$, J. Ribes ${ }^{2}$, A. Seco ${ }^{2}$ and J. Ferrer ${ }^{1}$ \\ ${ }^{1}$ Instituto de Ingeniería del Agua y Medio Ambiente. Universidad Politécnica de Valencia. Camino de Vera s/n. \\ 46022 Valencia. Spain. Tel.: (+34) 963879618; fax: (+34) 963877617. (E-mail: rababa@dihma.upv.es; \\ jserralt@hma.upv.es; emjidou@upvnet.upv.es; jerrer@hma.upv.es) \\ ${ }^{2}$ Dpto. Ingeniería Química. Universitat de València. Avinguda de la Universitat, s/n 46100 Burjassot. Valencia. \\ Spain. (E-mail: m.victoria.ruano@uv.es; josep.ribes@uv.es; aurora.seco@uv.es)
}

\begin{abstract}
This paper presents the plant-wide model Biological Nutrient Removal Model $\mathrm{N}^{\mathrm{o}} 2$ (BNRM2). Since nitrite was not considered in the BNRM1, and this previous model also failed to accurately simulate the anaerobic digestion because precipitation processes were not considered, an extension of BNRM1 has been developed. This extension comprises all the components and processes required to simulate nitrogen removal via nitrite and the formation of the solids most likely to precipitate in anaerobic digesters. The solids considered in BNRM2 are: struvite, amorphous calcium phosphate, hidroxiapatite, newberite, vivianite, strengite, variscite, and calcium carbonate. With regard to nitrogen removal via nitrite, appart from nitrite oxidising bacteria two groups of ammonium oxidising organisms (AOO) have been considered since different sets of kinetic parameters have been reported for the AOO present in activated sludge systems and SHARON reactors. Due to the new processes considered, BNRM2 allows an accurate prediction of WWTPs performance in wider environmental and operating conditions.
\end{abstract}

Keywords

Activated sludge models; BNRM1; Nitrite; Plant-wide mathematical modelling; Precipitation

\section{INTRODUCTION}

Whole wastewater treatment plant modelling is one of the most important topics for the scientific community. This issue has been tackled by two philosophical approaches: using separated models (which were developed for the different process units) that are connected to simulate the whole plant, or using one unique and general model for the whole plant. In 2004, the CALAGUA research group published the Biological Nutrient Removal Model $N^{0} 1$ (BNRM1, Seco et al., 2004) including different physical, chemical and biological processes taking place in a WWTP. The physical processes included were: settling and clarification processes (flocculated settling, hindered settling and thickening), volatile fatty acids elutriation and gas-liquid transfer. The chemical interactions considered were acid-base processes, where equilibrium conditions are assumed. The biological processes included were: organic matter, nitrogen and phosphorus removal; acidogenesis, acetogenesis and methanogenesis. This model has been successfully applied for the design and optimization of numerous WWTPs (Ruano et al., 2010). However, these applications showed that nitrogen removal via nitrite and chemical precipitation processes should be considered to properly simulate WWTPs.

Nitrogen removal via nitrite was initially applied in side stream processes (Hellinga et al., 1998). Savings in aeration costs of $25 \%$ are reached in comparison with conventional nitrification to nitrate. Moreover, subsequent denitrification consumes $40 \%$ less carbon source (Hellinga et al., 1998). Nitrogen removal via nitrite can be carried out in activated sludge reactors operated at short sludge retention time (SRT) and low dissolved oxygen (DO) concentrations. This process is particularly important in those WWTPs with low influent COD: $N$ ratio. Biologically induced precipitation, which is frequently reported in the literature, causes important operational problems 
in anaerobic digestion and downstream processes such as: pipe blockage and precipitates accumulation on the surfaces of different sludge management devices such as centrifuges and pumps (see Doyle and Parsons (2002) for a detailed review). Although struvite (magnesium ammonium phosphate) is the most important precipitate reported in WWTPs, Barat et al. (2009) detected an important precipitation of calcium phosphate jointly with struvite during anaerobic digestion. Furthermore, recent studies (Barat et al., 2008) have observed that phosphorus precipitation during the biological phosphorus removal process could affect the metabolism of Polyphosphate Accumulating Organisms (PAOs). Due to the importance of precipitation and nitrogen removal processes to properly simulate WWTPs, an extension of BNRM1 has been developed. The new model (Biological Nutrient Removal Model No.2, BNRM2) that is presented in this paper includes the results of the work carried out by the CALAGUA research group on mathematical modelling (Barat et al., 2011, Jiménez 2010). The new processes included in BNRM2 are the formation of 8 different precipitates and all the processes involved in the nitrogen removal via nitrite considering two groups of Ammonia Oxidising Organisms (AOO).

\section{MODEL DESCRIPTION}

The model considers the most important physical, chemical and biological processes taking place in a WWTP to maximize its potential applicability. The physical processes included are: settling and clarification processes (flocculated settling, hindered settling and thickening), volatile fatty acids (VFA) elutriation and gas-liquid transfer. The chemical interactions included comprise acid-base and ion-pairing processes, where equilibrium conditions are assumed, and precipitation processes. The biological processes included are: organic matter, nitrogen and phosphorus removal; acidogenesis, acetogenesis and methanogenesis. As a general model, BNRM2 considers the possible growth of all the bacterial groups included in the model in each operation unit. The environmental conditions (aerobic, anoxic or anaerobic) will determine which bacterial groups can proliferate. This "natural selection" observed in WWTPs is modelled by including switching functions for electron acceptors in the kinetic expressions.

The settling processes model (Ribes et al., 2002) consists in a one-dimensional model based on both the solids flux concept and the conservation of mass. The settling velocity is obtained by using the model proposed by Takács et al. (1991) for the flocculated and hindered settling. The settling velocity in the lower layers is corrected by a compression function similar to the one proposed by Otterpohl and Freund (1992). This model is linked to the biological model in order to consider the biological processes taking place in primary and secondary settlers, and gravity thickeners.

\section{Components in the model}

The model considers 42 components split in 19 soluble and 23 suspended components that are defined below:

$\mathrm{S}_{\mathrm{Ac}}\left[\mathrm{g} \mathrm{COD} \mathrm{m} \mathrm{m}^{-3}\right]$ : Acetate.

$\mathrm{S}_{\mathrm{CH} 4}\left[\mathrm{~g} \mathrm{COD} \mathrm{m}^{-3}\right.$ ]: Dissolved methane.

$\mathrm{S}_{\mathrm{F}}\left[\mathrm{g} \mathrm{COD} \mathrm{m}^{-3}\right.$ ]: Fermentable readily biodegradable substrate. It does not include VFA.

$\mathrm{S}_{\mathrm{H}}\left[\mathrm{kmol} \mathrm{H} \mathrm{m}^{-3}\right]$ : Total proton concentration. This component includes free protons and those associated with acidic components.

$\mathrm{S}_{\mathrm{H} 2}\left[\mathrm{~g} \mathrm{COD} \mathrm{m}^{-3}\right]$ : Dissolved hydrogen.

$\mathrm{S}_{\mathrm{U}}\left[\mathrm{g}\right.$ COD m $\left.\mathrm{m}^{-3}\right]$ : Inert soluble organic material.

$\mathrm{S}_{\mathrm{Ig}, \mathrm{C}}\left[\mathrm{kmol} \mathrm{C} \mathrm{m}{ }^{-3}\right]$ : Inorganic carbon. It consists of $\mathrm{CO}_{2}, \mathrm{HCO}_{3}{ }^{-}$and $\mathrm{CO}_{3}{ }^{2-}$. For all stoichiometric computations $\mathrm{S}_{\text {IC }}$ is assumed to be $\mathrm{CO}_{2}$. 
$\mathrm{S}_{\mathrm{N} 2}\left[\mathrm{~g} \mathrm{~N} \mathrm{~m}^{-3}\right]$ : Dinitrogen $\left(\mathrm{N}_{2}\right)$.

$\mathrm{S}_{\mathrm{NHx}}\left[\mathrm{g} \mathrm{N} \mathrm{m}^{-3}\right]$ : Ammonium plus ammonia nitrogen.

${ }^{*} \mathrm{~S}_{\mathrm{NO} 2}\left[\mathrm{~g} \mathrm{~N} \mathrm{~m}^{-3}\right.$ ]: Total nitrite concentration. This component is the sum of nitrite and free nitrous acid concentrations.

$\mathrm{S}_{\mathrm{NO} 3}\left[\mathrm{~g} \mathrm{~N} \mathrm{~m}^{-3}\right]$ : Nitrate.

$\mathrm{S}_{\mathrm{O} 2}\left[\mathrm{~g} \mathrm{O}_{2} \mathrm{~m}^{-3}\right]$ : Dissolved oxygen.

$\mathrm{S}_{\mathrm{PO} 4}\left[\mathrm{~g} \mathrm{P} \mathrm{m}^{-3}\right]$ : Orthophosphates.

$\mathrm{S}_{\mathrm{VFA}}\left[\mathrm{g} \mathrm{COD} \mathrm{m}^{-3}\right]$ : Fermentation products except acetate. It is assumed to be propionate.

${ }^{*} \mathrm{~S}_{\mathrm{Ca}}\left[\mathrm{g} \mathrm{Ca} \mathrm{m}^{-3}\right.$ ]: Total soluble inorganic calcium concentration.

${ }^{*} \mathrm{~S}_{\mathrm{Mg}}\left[\mathrm{g} \mathrm{Mg} \mathrm{m}^{-3}\right.$ ]: Total soluble inorganic magnesium concentration.

${ }^{*} \mathrm{~S}_{\mathrm{K}}\left[\mathrm{g} \mathrm{K} \mathrm{m}^{-3}\right]$ : Total soluble inorganic potassium concentration.

${ }^{*} \mathrm{~S}_{\mathrm{Fe}}$ [g Fe m${ }^{-3}$ ]: Total soluble inorganic iron concentration.

${ }^{*} \mathrm{~S}_{\mathrm{Al}}\left[\mathrm{g} \mathrm{Al} \mathrm{m}^{-3}\right.$ ]: Total soluble inorganic aluminium concentration.

$\mathrm{X}_{\mathrm{PRO}}\left[\mathrm{g} \mathrm{COD} \mathrm{m}^{-3}\right]$ : Acetogenic bacteria.

$\mathrm{X}_{\mathrm{AO}}\left[\mathrm{g}\right.$ COD m$\left.{ }^{-3}\right]$ : Acidogenic bacteria.

$\mathrm{X}_{\mathrm{OHO}}\left[\mathrm{g} \mathrm{COD} \mathrm{m}^{-3}\right.$ ]: Heterotrophic organisms. They may grow aerobically and anoxically.

${ }^{*} \mathrm{X}_{\mathrm{AOO}, \mathrm{r}}$ [g COD $\mathrm{m}^{-3}$ ]: Ammonium oxidizing organisms (r-strategist). These organisms are responsible for ammonium oxidation to nitrite.

${ }^{*} \mathrm{X}_{\mathrm{AOO}, \mathrm{K}}\left[\mathrm{g} \mathrm{COD} \mathrm{\textrm {m } ^ { - 3 }}\right.$ ]: Ammonium oxidizing organisms (K-strategist). These organisms are responsible for ammonium oxidation to nitrite.

${ }^{*} \mathrm{X}_{\mathrm{NOO}}$ [g COD m $\mathrm{g}^{-3}$ ]: Nitrite oxidizing organisms. These organisms are responsible for nitrite oxidation to nitrate.

$\mathrm{X}_{\mathrm{U}}\left[\mathrm{g} \mathrm{COD} \mathrm{m}^{-3}\right.$ ]: Inert particulate organic material.

$\mathrm{X}_{\mathrm{ACO}}\left[\mathrm{g}\right.$ COD m $\mathrm{m}^{-3}$ ]: Methanogenic acetoclastic organisms.

$\mathrm{X}_{\mathrm{HMO}}\left[\mathrm{g} \mathrm{COD} \mathrm{\textrm {m } ^ { - 3 }}\right.$ ]: Methanogenic hydrogenotrophic organisms.

$\mathrm{X}_{\mathrm{PAO}}\left[\mathrm{g}\right.$ COD m $\mathrm{m}^{-3}$ ]: Polyphosphate Accumulating Organisms (PAOs).

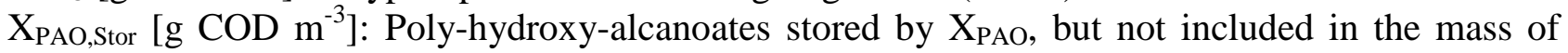

$\mathrm{X}_{\mathrm{PAO}}$

$\mathrm{X}_{\mathrm{PAO}, \mathrm{PP}}\left[\mathrm{g} \mathrm{P} \mathrm{m}^{-3}\right]$ : Poly-phosphates stored by $\mathrm{X}_{\mathrm{PAO}}$, but not included in the mass of $\mathrm{X}_{\mathrm{PAO}}$.

$\mathrm{XC}_{\mathrm{B}}\left[\mathrm{g} \mathrm{COD} \mathrm{m}^{-3}\right.$ ]: Slowly biodegradable substrates.

$\mathrm{X}_{\mathrm{TSS}}$ [g COD m $\mathrm{g}^{-3}$ ]: Total suspended solids.

$\mathrm{X}_{\mathrm{NVSs}}$ [g COD m${ }^{-3}$ ]: Influent non-volatile suspended solids.

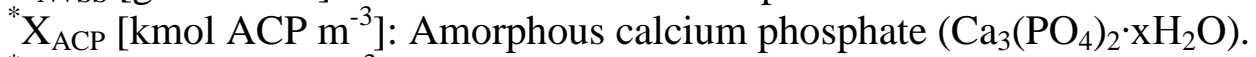

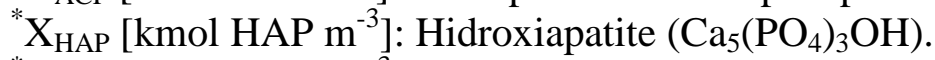

${ }^{*} \mathrm{X}_{\text {MAP }}\left[\mathrm{kmol} \mathrm{MAP} \mathrm{m}{ }^{-3}\right]$ : Struvite $\left(\mathrm{MgNH}_{4} \mathrm{PO}_{4} \cdot 6 \mathrm{H}_{2} \mathrm{O}\right)$.

${ }^{*} \mathrm{X}_{\text {New }}\left[\mathrm{kmol} \mathrm{New} \mathrm{m}{ }^{-3}\right]$ : Newberite $\left(\mathrm{MgHPO}_{4} \cdot 3 \mathrm{H}_{2} \mathrm{O}\right)$.

${ }^{*} \mathrm{X}_{\text {Viv }}\left[\mathrm{kmol} \mathrm{Viv} \mathrm{m}{ }^{-3}\right]$ : Vivianite $\left(\mathrm{Fe}_{3}\left(\mathrm{PO}_{4}\right)_{2} \cdot 8 \mathrm{H}_{2} \mathrm{O}\right)$.

${ }^{*} \mathrm{X}_{\text {Str }}\left[\mathrm{kmol} \mathrm{Str} \mathrm{m}^{-3}\right]$ : Strengite $\left(\mathrm{FePO}_{4}\right)$.

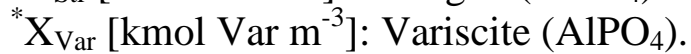

${ }^{*} \mathrm{X}_{\mathrm{Cal}}\left[\mathrm{kmol} \mathrm{Cal} \mathrm{m}{ }^{-3}\right]$ : Calcium carbonate $\left(\mathrm{CaCO}_{3}\right)$.

${ }^{*}$ New components included in BNRM2

All these components and the model notation are defined by following the nomenclature proposed by Corominas et al. (2010).

Since previous research (Claros et al., 2010; Jiménez, 2010) has shown that model parameter values required to reproduce the $\mathrm{AOO}$ behaviour in SHARON and activated sludge reactors are significantly different, two $\mathrm{AOO}$ groups $\left(\mathrm{X}_{\mathrm{AOO}, \mathrm{r}}, \mathrm{X}_{\mathrm{AOO}, \mathrm{K}}\right)$ are considered in BNRM2. This approach, which is similar to the one proposed by Wett et al. (2011), is also based on bacterial quantification 
results using FISH technique. These results have proven that the conditions prevailing in the SHARON reactor (short SRT, high substrate concentrations) promote the development of rstrategist species (high growth rate and low substrate affinity), such as Nitrosomonas europaea and Nitrosomonas eutropha; while the conditions prevailing in activated sludge reactors (long SRT, low substrate concentrations) promote the development of K-strategist species (low growth rate and high substrate affinity), such as Nitrosomonas oligotropha (Manser et al., 2005; Claros et al., 2010).

The components $\mathrm{S}_{\mathrm{Mg}}, \mathrm{S}_{\mathrm{Ca}}, \mathrm{S}_{\mathrm{K}}, \mathrm{S}_{\mathrm{Fe}}, \mathrm{S}_{\mathrm{Al}}$ represent the sum of the ion concentration (e.g. $\mathrm{Ca}^{2+}$ ) and the ion present in other inorganic dissolved species (e.g. $\mathrm{CaOH}^{+}, \mathrm{CaPO}_{4}{ }^{-}, \mathrm{CaHCO}_{3}{ }^{+}$). The solids most likely to precipitate (Maurer et al., 1999; Musvoto et al., 2000b) are various magnesium and calcium phosphates, calcium carbonate, iron phosphates and aluminium phosphate, which have been included as new components in the model.

\section{Kinetic processes}

The developed model considers a total of 60 kinetically governed processes (39 biological, 15 chemical and 6 physical processes) which are shown in Table 1. In appendix A the stoichiometric matrix of all these processes is shown.

Besides the continuity equations for the elements included in the BNRM1 (Chemical oxygen demand, inorganic carbon, proton, suspended solids, nitrogen and phosphorus) the following elements, which are involved in the precipitation processes, have been included in order to guarantee its continuity in the model: calcium, magnesium, aluminium, iron and potassium. Although potassium is not directly involved in the precipitation processes it has been included in BNRM2 due to its requirement to maintain the polyphosphate electroneutrality together with magnesium (Barat et al., 2005). Appendix A (Table A2 and Table A4) shows the conversion factors to be applied in the continuity equations for all the elements considered in BNRM2. The content of $\mathrm{Fe}$ and $\mathrm{Al}$ in the organic compounds and biomass could be assumed to be negligible.

In BNRM2 the stoichiometry of both biological processes carried out by $\mathrm{X}_{\mathrm{AOO}, \mathrm{r}}$ and $\mathrm{X}_{\mathrm{AOO}, \mathrm{K}}$ is the same (see appendix A Table A1 and Table A3). However, this model considers two different groups of AOO because they present different maximum growth rates and substrate and dissolved oxygen affinities (Jiménez, 2010). As regards the stoichiometry for the denitrification processes, although nitrite can be detected as intermediate in denitrification process under specific conditions, this model considers that nitrate is directly converted to nitrogen gas as it is modelled by Hellinga et al. (1998) and Volcke (2006). This assumption was made according to our denitrification experiments carried out with urban wastewater where nitrite was not detected during nitrate removal.

In appendix B the kinetic expressions of all the processes considered in BNRM2 are listed. Two different $\mathrm{pH}$ inhibition functions are considered in BNRM2 (see Appendix B Table B1): a combination of Monod and non-competitive inhibition functions ( $\mathrm{I}_{\mathrm{pH} 1}$ equation 1) and a sigmoidal function ( $\mathrm{I}_{\mathrm{pH} 2}$ equation 2). This sigmoidal function is only used to model the growth of $\mathrm{X}_{\mathrm{NOO}}$ because the $\mathrm{I}_{\mathrm{pH} 1}$ type function was not able to reproduce the sharp activity decrease observed at low pH values (Jiménez et al., 2011).

$$
I_{p H 1}=\frac{\frac{S_{[H]}}{K_{S, H}+S_{[H]}} \cdot \frac{K_{I, H}}{K_{I, H}+S_{[H]}}}{\frac{S_{[H], O p t}}{K_{S, H}+S_{[H], O p t}} \cdot \frac{K_{I, H}}{K_{I, H}+S_{[H], O p t}}}
$$

$$
I_{p H 2}=\frac{1}{1+e^{\left[A_{H}\left(K_{S, p H}-p H\right)\right]}}
$$


In these equations $\mathrm{S}_{[\mathrm{H}] \text {,Opt }}$ represents the optimum proton concentration obtained as $\sqrt{K_{I, H} \cdot K_{S, H}}$, and $\mathrm{A}_{\mathrm{H}}$ is a fitting parameter.

Table 1. Kinetic processes considered in BNRM2.

\begin{tabular}{|c|c|}
\hline \multicolumn{2}{|c|}{ Biological processes } \\
\hline Heterotrophic Bacteria & Polyphosphate Accumulating Bacteria \\
\hline 1. Aerobic hydrolysis & 14. Storage of $\mathrm{X}_{\mathrm{PAO}, \mathrm{Stor}}$ over $\mathrm{S}_{\mathrm{Ac}}$ \\
\hline 2. Anoxic hydrolysis & 15. Storage of $\mathrm{X}_{\mathrm{PAO}, \text { Stor }}$ over $\mathrm{S}_{\mathrm{VFA}}$ \\
\hline 3. Anaerobic hydrolysis & 16. Aerobic storage of $\mathrm{X}_{\mathrm{PAO}, \mathrm{PP}}$ \\
\hline 4. Aerobic growth of $\mathrm{X}_{\mathrm{OHO}}$ over $\mathrm{S}_{\mathrm{F}}$ & 17. Anoxic storage of $\mathrm{X}_{\mathrm{PAO}, \mathrm{PP}}$ over $\mathrm{S}_{\mathrm{NO} 3}$ \\
\hline 5. Aerobic growth of $\mathrm{X}_{\mathrm{OHO}}$ over $\mathrm{S}_{\mathrm{Ac}}$ & ${ }^{*}$ 18. Anoxic storage of $\mathrm{X}_{\mathrm{PAO}, \mathrm{PP}}$ over $\mathrm{S}_{\mathrm{NO} 2}$ \\
\hline 6. Aerobic growth of $\mathrm{X}_{\mathrm{OHO}}$ over $\mathrm{S}_{\mathrm{VFA}}$ & 19. Aerobic growth of $\mathrm{X}_{\mathrm{PAO}}$ \\
\hline 7. Anoxic growth of $\mathrm{X}_{\mathrm{OHO}}$ over $\mathrm{S}_{\mathrm{F}}$ and $\mathrm{S}_{\mathrm{NO} 3}$ & 20. Anoxic growth of $\mathrm{X}_{\mathrm{PAO}}$ over $\mathrm{S}_{\mathrm{NO} 3}$ \\
\hline 8. Anoxic growth of $\mathrm{X}_{\mathrm{OHO}}$ over $\mathrm{S}_{\mathrm{Ac}}$ and $\mathrm{S}_{\mathrm{NO} 3}$ & ${ }^{*} 21$. Anoxic growth of $\mathrm{X}_{\mathrm{PAO}}$ over $\mathrm{S}_{\mathrm{NO} 2}$ \\
\hline 9. Anoxic growth of $\mathrm{X}_{\mathrm{OHO}}$ over $\mathrm{S}_{\mathrm{VFA}}$ and $\mathrm{S}_{\mathrm{NO} 3}$ & 22. Lysis of $\mathrm{X}_{\mathrm{PAO}}$ \\
\hline *10. Anoxic growth of $\mathrm{X}_{\mathrm{OHO}}$ over $\mathrm{S}_{\mathrm{F}}$ and $\mathrm{S}_{\mathrm{NO} 2}$ & 23. Lysis of $\mathrm{X}_{\mathrm{PAO}, \mathrm{PP}}$ \\
\hline *11. Anoxic growth of $\mathrm{X}_{\mathrm{OHO}}$ over $\mathrm{S}_{\mathrm{Ac}}$ and $\mathrm{S}_{\mathrm{NO} 2}$ & 24. Lysis of $\mathrm{X}_{\mathrm{PAO}, \mathrm{Stor}}$ \\
\hline \multicolumn{2}{|l|}{$\begin{array}{l}\text { 12. Anoxic growth of } \mathrm{X}_{\mathrm{OHO}} \text { over } \mathrm{S}_{\mathrm{VFA}} \text { and } \mathrm{S}_{\mathrm{NO} 2} \\
\text { 13. Lysis of } \mathrm{X}_{\mathrm{OHO}}\end{array}$} \\
\hline Ammonium Oxidizing Bacteria-r & Ammonium Oxidizing Bacteria-K \\
\hline 25. Aerobic growth of $\mathrm{X}_{\mathrm{AOO}, \mathrm{r}}$ & *27. Aerobic growth of $\mathrm{X}_{\mathrm{AOO}, \mathrm{K}}$ \\
\hline *26. Lysis of $\mathrm{X}_{\mathrm{AOO}, \mathrm{r}}$ & *28. Lysis of $\mathrm{X}_{\mathrm{AOO}, \mathrm{K}}$ \\
\hline Nitrite Oxidizing Bacteria & Acidogenic Bacteria \\
\hline *29. Aerobic growth of $\mathrm{X}_{\mathrm{NOO}}$ & 31. Anaerobic hydrolysis \\
\hline${ }^{*} 30$. Lysis of $\mathrm{X}_{\mathrm{NOO}}$ & 32. Anaerobic growth of $X_{\mathrm{AO}}$ \\
\hline & 33. Lysis of $\mathrm{X}_{\mathrm{AO}}$ \\
\hline Acetogenic Bacteria & Methanogenic Hydrogenotrophic Bacteria \\
\hline 34. Anaerobic growth of $\mathrm{X}_{\mathrm{PRO}}$ & 36. Anaerobic growth of $\mathrm{X}_{\mathrm{HMO}}$ \\
\hline 35. Lysis of $\mathrm{X}_{\mathrm{PRO}}$ & 37. Lysis of $\mathrm{X}_{\mathrm{HMO}}$ \\
\hline \multicolumn{2}{|l|}{ Methanogenic Acetoclastic Bacteria } \\
\hline \multicolumn{2}{|l|}{$\begin{array}{l}\text { 38. Anaerobic growth of } \mathrm{X}_{\mathrm{ACO}} \\
\text { 39. Lysis of } \mathrm{X}_{\mathrm{ACO}}\end{array}$} \\
\hline \multicolumn{2}{|c|}{ Physical processes } \\
\hline 40. Stripping of $\mathrm{S}_{[\mathrm{CO} 2]}$ & 43. Stripping of $\mathrm{S}_{\mathrm{H} 2}$ \\
\hline 41. Stripping of $\mathrm{S}_{\mathrm{O} 2}$ & 44. Stripping of $\mathrm{S}_{\mathrm{N} 2}$ \\
\hline 42. Stripping of $\mathrm{S}_{\mathrm{CH} 4}$ & 45. Stripping of $\mathrm{S}_{[\mathrm{NH} 3]}$ \\
\hline \multicolumn{2}{|c|}{ Precipitation processes } \\
\hline *46. Precipitation of $\mathrm{X}_{\mathrm{ACP}}$ & "47. Dissolution of $\mathrm{X}_{\mathrm{ACP}}$ \\
\hline *48. Precipitation of $\mathrm{X}_{\mathrm{Str}}$ & *49. Dissolution of $X_{\text {Str }}$ \\
\hline *50. Precipitation of $\mathrm{X}_{\mathrm{MAP}}$ & *51. Dissolution of $\mathrm{X}_{\mathrm{MAP}}$ \\
\hline${ }^{*}$ 52. Precipitation of $\mathrm{X}_{\mathrm{New}}$ & *53. Dissolution of $X_{\mathrm{New}}$ \\
\hline *54. Precipitation of $\mathrm{X}_{\mathrm{Viv}}$ & *55. Dissolution of $\mathrm{X}_{\mathrm{Viv}}$ \\
\hline *56. Precipitation of $\mathrm{X}_{\mathrm{Var}}$ & *57. Dissolution of $\mathrm{X}_{\mathrm{Var}}$ \\
\hline *58. Precipitation of $\mathrm{X}_{\mathrm{Cal}}$ & *59. Dissolution of $\mathrm{X}_{\mathrm{Cal}}$ \\
\hline *60. Precipitation of $\mathrm{X}_{\mathrm{HAP}}$ & \\
\hline
\end{tabular}

BNRM2 considers different substrates to model the growth of both AOO groups (see Table B1 in Appendix B). The $\mathrm{X}_{\mathrm{AOO}, \mathrm{r}}$ growth rate depends on free ammonia concentration (Claros et al., 2010; van Hulle et al., 2007) while the $\mathrm{X}_{\mathrm{AOO}, \mathrm{K}}$ growth rate depends on total ammonium nitrogen concentration (Jiménez 2010 and Jiménez et al., 2012). 
With regard to the precipitation kinetics, the processes have been modelled as reversible processes, according to its oversaturated or undersaturated degree following the theory of Koutsoukos et al. (1980). However, $X_{H A P}$ has been considered as a stable solid (only precipitation and not dissolution) according to the results obtained by different authors (Koutsoukos et al., 1980; Maurer et al. 1999). Furthermore, the precipitation rates have been modelled as surface controlled processes (Maurer et al., 1999; Musvoto et al., 2000a).

A sign() function is included in the kinetic expressions related to the precipitation and dissolution processes (see Appendix B, Table B1). This sign() function is defined as the sign $(+1,0,-1)$ of the saturation index (SI) for each precipitate. For instance, when the solution is oversaturated, SI is positive $(+1)$, the function (1-sign $\left.\left(\mathrm{SI}_{\mathrm{X}}\right)\right) / 2$ that is included in the dissolution kinetic is zero and the dissolution process rate is zero. In this case, the function $\left(1+\operatorname{sign}\left(\mathrm{SI}_{\mathrm{X}}\right)\right) / 2$ that is included in the precipitation kinetic is one and consequently the precipitation process takes place.

\section{Equilibrium governed processes}

As can be seen in the aforementioned equations the kinetic expressions of the processes considered make necessary the chemical equilibrium calculation in order to know the concentration of the inorganic soluble components under its different species (e.g. $\mathrm{Ca}^{2+}, \mathrm{PO}_{4}{ }^{3-}, \mathrm{NH}_{4}{ }^{+}, \mathrm{NH}_{3}, \mathrm{H}^{+}, \mathrm{HNO}_{2}$ ) which are involved in the precipitation and some biological processes.

BNRM2 includes, as equilibrium governed processes, the acid-base, ion-pairing and redox reactions in which any of the components are involved. In order to solve the chemical equilibrium, it was distinguished between components and species. Chemically, the aqueous phase system is represented by a set of components and a set of species. A species is defined as every chemical entity to be considered. For the set of species selected, a set of components is chosen so that each species can be written as the product of a reaction involving only components, and no component can be written as the product of a reaction involving other components. With this chemical representation, two characteristic variables are defined: the species concentration, $C_{i}\left(\mathrm{ML}^{-3}\right)$, and the component concentration, $T_{j}\left(\mathrm{ML}^{-3}\right)$, being $T_{j}$ the sum of concentration of all the species in which this component participates. The species that can be formed from the components are listed on the matrix of components-species shown in Appendix C, Table C1.

This equilibrium is described by a set of non-linear algebraic equations including one law of mass action (eq. 3) for each species formed in each equilibrium system and one mass balance (eq.4) for each component. The redox reactions are solved using the Nerst equation. The application of these equations is described in Appendix C.

Law of mass action: $\quad x_{i}=K_{i} \cdot \prod_{j=1}^{N_{C}} x_{j}^{a_{i j}} \quad i=1,2 \ldots N_{s p}$ (number of species)

Mass balance: $\quad T_{j}=\sum_{i=1}^{N_{s p}} a_{i j} \cdot C_{i} \quad j=1,2 \ldots N_{C}$ (number of components)

where $x_{i}$ is the activity of the $i^{\text {th }}$ species, $x_{j}$ is the activity of the $j^{\text {th }}$ component, $a_{i j}$ is the stoichiometric coefficient of the $j^{\text {th }}$ component in the $i^{\text {th }}$ species (see Appendix C, Table C1), $K_{i}$ is the stability constant of the $i^{\text {th }}$ species corrected for temperature variations by the van't Hoff equation and $C_{i}$ is the concentration of the $i^{\text {th }}$ species. $N_{s p}$ is the number of species considered (93 in this case) and $N_{C}$ is the number of components (15 in this case). The activity and concentration of every component or species are related through the correspondent activity coefficient that depends on the ionic strength (Davis equation): 
$x_{i}=\gamma_{i} C_{i} \quad i=1,2, \ldots N_{s p}$

where $\gamma_{i}$ is the activity coefficient for the $i^{\text {th }}$ species. This chemical model is described in detail elsewhere (Serralta et al., 2004; Barat et al., 2011).

Instead of using the charge balance, the BNRM2 considers a mass-balance for proton component as proposed in the software MINTEQA2 (Allison et al., 1991). Therefore, proton is included as a component in the model. Since the unit of this component is $\mathrm{kmol} \mathrm{H}^{+} \cdot \mathrm{m}^{-3}$, a continuity equation for $\mathrm{H}^{+}$is applied to calculate the variation of total proton concentration in biological processes. Conversion factors $i_{\mathrm{H} \_i}$ are defined to apply the continuity equation (see Appendix A, Table A2 and Table A4).

It should be highlighted that the consideration of the acid-base and the ion-paring interactions as equilibrium governed processes hugely simplifies the numerical solution and the model calibration due to the absence of kinetic parameters to solve the aqueous equilibrium.

\section{Simulation procedure}

The simulation procedure involves a sequential iteration among the differential equations obtained from the kinetic governed processes (biological and precipitation model) and the algebraic equations obtained from the equilibrium governed processes (chemical model). The total concentration of each component (e.g. $\mathrm{S}_{\mathrm{PO} 4}$ and $\mathrm{S}_{\mathrm{NHx}}$ ) needed for applying the chemical model, is provided by the solution of mass-balance equations. The concentrations of the species (e.g. $\left.\mathrm{S}_{[\mathrm{PO} 4}{ }^{3-}\right]$,

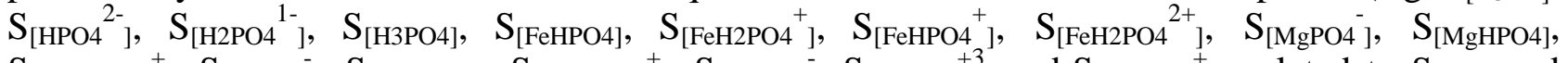

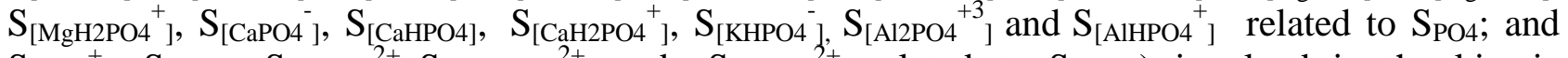
$\left.\left.\left.\mathrm{S}_{[\mathrm{NH} 4}{ }^{+}\right], \mathrm{S}_{[\mathrm{NH} 3]}, \mathrm{S}_{[\mathrm{CaNH} 3}{ }^{2+}\right], \mathrm{S}_{[\mathrm{Ca}(\mathrm{NH} 3) 2}{ }^{2+}\right]$ and $\mathrm{S}_{[\mathrm{FeNH} 3}{ }^{2+}$ ] related to $\mathrm{S}_{\mathrm{NHx}}$ ) involved in the kinetic expressions are provided by the solution of the chemical equilibrium.

The use of MINTEQA2 (Allison et al., 1991) is recommended in order to solve the chemical model due to the high number of species involved. The main advantages of using this software can be summarised as:

- The chemical algebraic equations are already implemented in the software.

- The equilibrium composition is thoroughly calculated: temperature variations of equilibrium constants are taken into account, activity coefficient of each species is calculated to apply the law of mass action.

- The model can be easily enlarged because the equations required to calculate the equilibrium composition considering new components are already implemented.

- MINTEQA2 calculates the redox reaction $\mathrm{Fe}^{2+} / \mathrm{Fe}^{3+}$ using the Nerst equation. In this respect, this software requires the redox potential value that should be defined in the simulation platform for each element of the WWTP.

The data required to predict the equilibrium composition consist of total dissolved concentrations for the components of interest. As in this case the equilibrium calculation is linked to dynamic biological processes, the total concentration of each component is provided by the solution of mass balance equations. MINTEQA2 original code has been slightly modified and compiled through the dynamic link library (DLL) techniques, allowing the FORTRAN module to be linked promptly to every program working with Windows system. In this respect, MINTEQA2 obtains the required 
information from the software solving the mass balance differential equations and can be applied in an iterative calculation. A schematic diagram of the solution procedure is shown in Fig. 1.

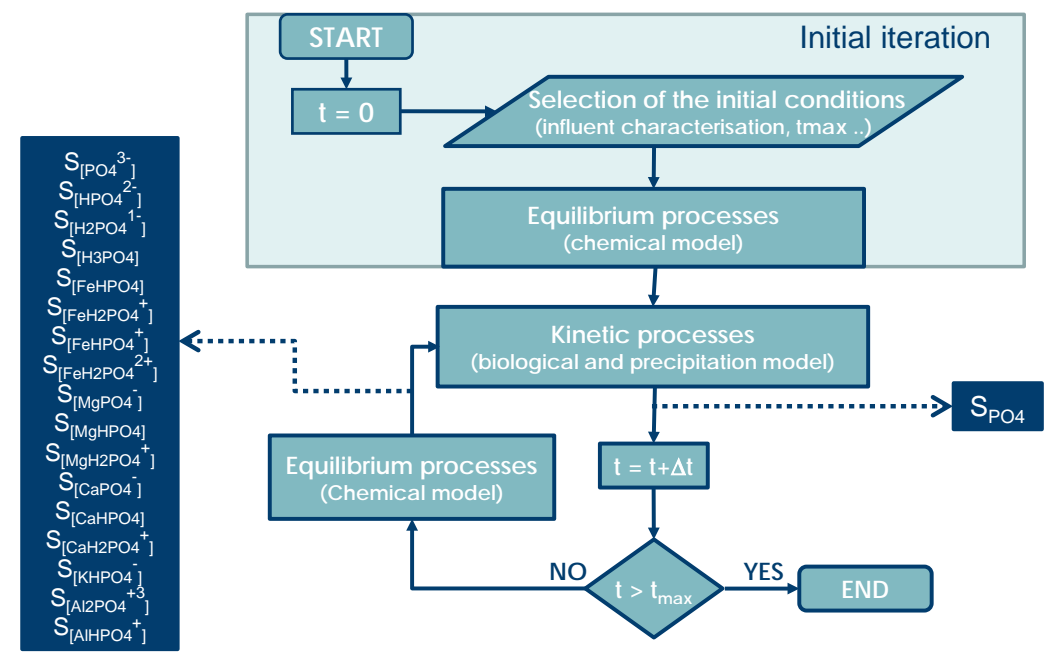

Figure 1. Schematic diagram of the proposed solution procedure to solve BNRM2.

\section{MODEL VALIDATION}

Different batch experiments were carried out in a laboratory scale SHARON reactor to determine the most important parameters related to $\mathrm{X}_{\mathrm{AOO}, \mathrm{r}}$. Bacterial activity was measured as oxygen uptake rate (OUR) at different $\mathrm{pH}$ values (ranging from 6 to 9), substrate concentrations (from 45 to 10000 mg $\mathrm{NH}_{4}-\mathrm{N} \cdot \mathrm{L}^{-1}$ ), dissolved oxygen concentrations (from 0.1 to $6 \mathrm{mg} \mathrm{O}_{2} \cdot \mathrm{L}^{-1}$ ) and nitrite concentrations (from 75 to $5000 \mathrm{mg} \mathrm{NO}-\mathrm{N} \cdot \mathrm{L}^{-1}$ ). These experiments allowed to determine the following parameters related to $\mathrm{X}_{\mathrm{AOO}, \mathrm{r}}$ : $\mu_{\mathrm{AOO}, \mathrm{r}, \mathrm{Max}}, \mathrm{K}_{[\mathrm{NH}], \mathrm{AOO}, \mathrm{r}}, \mathrm{K}_{\mathrm{O} 2, \mathrm{AOO}, \mathrm{r}}, \mathrm{K}_{\mathrm{I},[\mathrm{HNO}], \mathrm{AOO}, \mathrm{r}}, \mathrm{K}_{\mathrm{I}, \mathrm{pH}, \mathrm{AOO}, \mathrm{r}}$, $\mathrm{K}_{\mathrm{s}, \mathrm{pH}, \mathrm{AOO}, \mathrm{r}}$, and $\mathrm{Y}_{\mathrm{AOO}, \mathrm{r}}$. The kinetic expression for the $\mathrm{X}_{\mathrm{AOO}, \mathrm{r}}$ growth was defined on the basis of the experimental results obtained. These results showed that free ammonia should be considered as the substrate for these bacteria and that the reduction observed in the biomass activity at high ammonium concentration was due to salinity and not to free ammonia concentrations. Further details related to the results obtained and the calibration methodology can be found at Jiménez (2010) and Claros et al. (2010).

In addition, the most important parameters related to $\mathrm{X}_{\mathrm{AOO}, \mathrm{K}}$ and $\mathrm{X}_{\mathrm{NOO}}$ were determined in different laboratory batch experiments using biomass from a nutrient removal pilot plant. With regard to $\mathrm{X}_{\mathrm{AOO}, \mathrm{K}}$ the following parameters were determined: $\mu_{\mathrm{AOO}, \mathrm{K}, \mathrm{Max}}, \mathrm{K}_{\mathrm{NHx}, \mathrm{AOO}, \mathrm{K}}, \mathrm{K}_{\mathrm{O} 2, \mathrm{AOO}, \mathrm{K}}, \mathrm{K}_{\mathrm{I},[\mathrm{HNO} \text { ],AOO,K}}$, $\mathrm{K}_{\mathrm{I}, \mathrm{pH}, \mathrm{AOO}, \mathrm{K}}, \mathrm{K}_{\mathrm{S}, \mathrm{pH}, \mathrm{AOO}, \mathrm{K}}$, and $\mathrm{Y}_{\mathrm{AOO}, \mathrm{K}}$. The experimental results obtained indicated that total ammonium concentration should be considered as the substrate for these bacteria. The different substrates for both AOO bacteria determined in the different experiments carried out, is one of the reasons to include two AOO groups in BNRM2. Concerning $\mathrm{X}_{\mathrm{NOO}}$ the following parameters were determined: $\mu_{\mathrm{NOO}, \mathrm{Max}}, \mathrm{K}_{\mathrm{NO} 2, \mathrm{NOO}}, \mathrm{K}_{\mathrm{O} 2 \text {,NOO}}, \mathrm{K}_{\mathrm{S}, \mathrm{pH}, \mathrm{NOO}}$, and $\mathrm{Y}_{\mathrm{NOO}}$. The experimental results obtained indicated that total nitrite concentration should be considered as the substrate for these bacteria and that $\mathrm{pH}$ values up to 9.9 did not affect $\mathrm{X}_{\mathrm{NOO}}$ growth rate. These experimental results contributed to define the kinetic expressions related to these bacteria. For further details about these experiments see Jiménez et al. (2011) and Jiménez et al. (2012). 
With regard to the calibration and validation of the precipitation and dissolution processes considered in BNRM2, six batch experiments were carried out in a SBR operated for enhanced biological phosphorus removal (EBPR). Figure 2 shows the experimental and simulated values of acetic acid, phosphate, $\mathrm{pH}$ (see Figure 2a), calcium, potassium and magnesium profiles (see Figure 2b) during one of the experiments. The results obtained in all the experiments (as Figure 2 shows) indicated that the model predictions accurately reproduced the corresponding experimental data, not only for the components related to chemical processes $\left(\mathrm{S}_{\mathrm{Ca}}\right.$ and $\mathrm{S}_{\mathrm{PO} 4}$ involved in calcium phosphate formation as $\mathrm{X}_{\mathrm{ACP}}$ and $\mathrm{X}_{\mathrm{HAP}}$ ) but also those components related to biological processes ( $\mathrm{S}_{\mathrm{PO} 4}, \mathrm{~S}_{\mathrm{VFA}}$, $\mathrm{S}_{\mathrm{K}}$ and $\mathrm{S}_{\mathrm{Mg}}$ involved in EBPR). For further details see Barat et al. (2011).

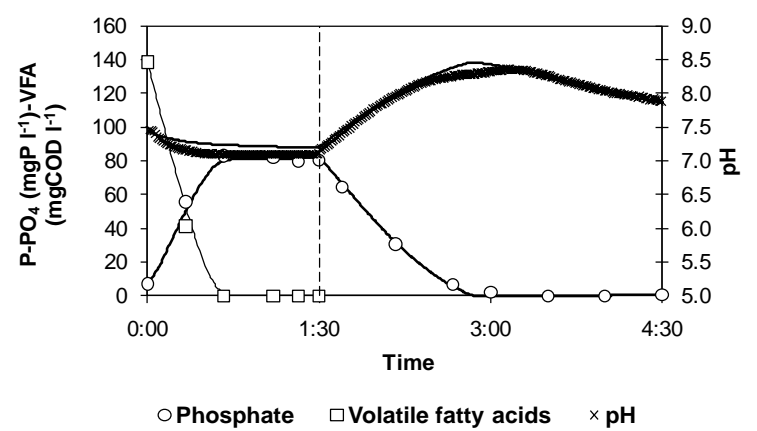

(a)

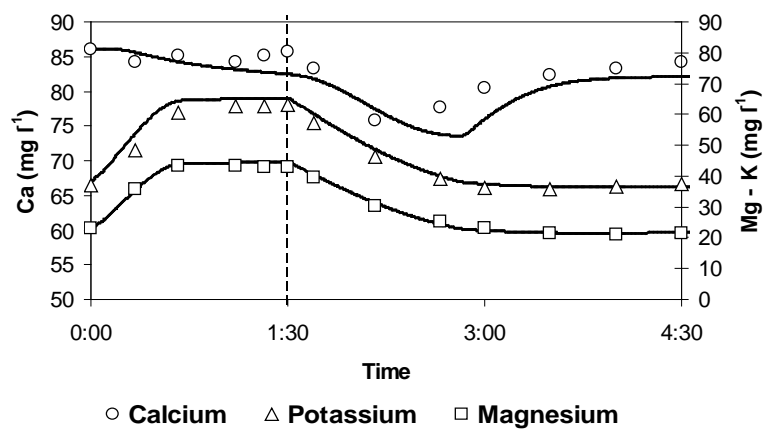

(b)

Figure 2. Experimental versus simulation results from an SBR operated for EBPR. Experimental data are plotted in dots and simulated data from BNRM2 are plotted in lines: (a) phosphate, volatile fatty acids and $\mathrm{pH}$; (b) calcium, potassium and magnesium.

\section{CONCLUSIONS}

The BNRM2 has been presented in this paper as an extension of the general model BNRM1. This extension comprises the formation of 8 different precipitates and all the processes involved in the nitrogen removal via nitrite considering two groups of $\mathrm{AOO}\left(\mathrm{X}_{\mathrm{AOO}, \mathrm{r}}, \mathrm{X}_{\mathrm{AOO}, \mathrm{K}}\right)$. Thus, optimum operation conditions and plant configuration to improve nitrogen removal, to minimize the uncontrolled phosphorus precipitation and to maximize phosphorus recovery in the recycled streams can be established with BNRM2 as this model considers the nitrogen removal over nitrite and precipitation processes. Further research is being carried out in order to include other processes that take place in WWTPs which are not yet considered in this model, such as the ones related to sulphur containing species, i.e. the biological processes (by means of sulphate reducing bacteria) and the physico-chemical processes (e.g. sulphide oxidation and sulphate precipitation).

\section{ACKNOWLEDGEMENT}

This research work has been supported by the Spanish Research Foundation (CICYT Projects, PPQ2002-04043-C02, CTM2005-06919-C03-/TECNO) and Entidad Pública de Saneamiento de Aguas Residuales de la Comunidad Valenciana which are gratefully acknowledged. This paper was presented at WWTmod2012 and the fruitful discussions are kindly acknowledged.

\section{REFERENCES}

Allison, J. D., Brown, D. S. \& Novo-Gradac K. J. 1991 MINTEQA2/ PRODEFA2, A Geochemical Assessment Model for Environmental Systems: Version 3.0. EPA/600/3-91/021, USEPA, Washington, D.C., USA.

Barat, R., Montoya, T., Seco, A. \& Ferrer, J. 2005 The role of potassium, magnesium and calcium in the enhanced biological phosphorus removal treatment plants. Environ. Technol. 26(9), 983-992. 
Barat, R., Montoya, T., Borras, L., Ferrer, J. \& Seco, A. 2008 Interactions between calcium precipitation and the polyphosphate-accumulating bacteria metabolism. Water Res. 42(13), 3415-3424.

Barat, R., Bouzas, A., Marti, N., Ferrer, J. \& Seco, A. 2009 Precipitation assessment in wastewater treatment plants operated for biological nutrient removal: a case study in Murcia, Spain. J. Environ. Manage. 90(2), 850-857.

Barat, R., Montoya, T., Seco, A. \& Ferrer, J. 2011 Modeling biological and chemically induced precipitation of calcium phosphate in enhanced biological phosphorus removal systems. Water Res. 45(12), 3744-3752.

Claros, J., Jiménez, E., Borrás, L., Aguado, D., Seco, A., Ferrer, J. \& Serralta, J. 2010 Short term effect of ammonia concentration and salinity on activity of ammonia oxidizing bacteria. Wat. Sci. Tech. 61(12), 3008-3016.

Corominas, Ll., Rieger, L., Takács, I., Ekama, G., Hauduc, H., Vanrolleghem, P.A. Oehmen, A., Gernaey, K. V., van Loosdrecht, M. C. M. \& Comeau, Y. 2010 New framework for standardized notation in wastewater treatment modelling. Wat. Sci. Tech. 61(4), 841-857.

Doyle, J. D. \& Parsons, S. A. 2002 Struvite formation, control and recovery. Water Res. 36(16), 3925-3940.

Hellinga, C., Schellen, A.A.J.C., Mulder, J.W., van Loosdrecht, M.C.M. \& Heijnen, J.J. 1998 The SHARON process: an innovate method for nitrogen removal from ammonia-rich wastewater. Wat. Sci. Tech. 37(9), 135-142.

Jiménez, E., 2010, Mathematical modeling of two-step nitrification process. Development of a calibration methodology applied to SHARON reactors and activated sludge processes, Ph.D. Thesis, Polytechnic University of Valencia (In Spanish), Spain.

Jiménez, E., Giménez, J. B., Ruano, M.V, Ferrer, J. \& Serralta, J. 2011 Effect of pH and nitrite concentration on nitrite oxidation rate. Bioresource Technol. 102(19), 8741-8747.

Jiménez, E., Giménez, J. B., Seco, A., Ferrer, J. \& Serralta, J. 2012 Effect of pH, substrate and free nitrous acid concentrations on ammonium oxidation rate. Bioresource Technol. In Press.

Koutsoukos, P., Amjad, Z., Tomson, M. B. \& Nancollas, G. H. 1980 Crystallization of calcium phosphates: a constant composition study. J. Am. Chem. Soc. 102(5), 1553-1557.

Manser, R., Gujer, W. \& Siegrist, H. 2005 Membrane bioreactor versus conventional activated sludge system: population dynamics of nitrifiers. Wat. Sci. Tech. 52(10-11), 417-425.

Maurer, M., Abramovich, D., Siegrist, H. \& Gujer, W. 1999 Kinetics of biologically induced phosphorus precipitation in waste-water treatment. Water Res. 33(2), 484-493.

Musvoto, E. V., Wentzel, M. C., Lowenthal, R. E. \& Ekama, G. A. 2000a Integrated chemical-physical processes modelling-I. Development of kinetic-based model for mixed weak acid/base systems. Water Res. 34(6), 18571867.

Musvoto, E. V., Wentzel, M. C. \& Ekama, G. A. 2000b Integrated chemical-physical processes modelling-II. Simulating aeration treatment of anaerobic digester supernatants. Water Res. 34(6), 1868-1880.

Otterpohl, R. \& Freund, M. 1992 Dynamic models for clarifiers of activated sludge plants with dry and wet weather flows. Wat. Sci. Tech. 26(5-6), 1391-1400.

Ribes, J., Ferrer, J., Bouzas, A. \& Seco, A. 2002 Modelling of an activated primary settling tank including the fermentation process and VFA elutriation. Environ. Technol. 23, 1147-1156.

Ruano, M.V., Serralta, J., Ribes, J., García-Usach, F., Bouzas, A., Barat, R., Seco, A. \& Ferrer, J. 2010 Benefits of using the Supermodel Biological Nutrient Removal Model No.1 for plant-wide modelling. In: 2nd IWA/WEF Wastewater Treatment Modelling Seminar WWTmod 2010 March 28-30, Mont-Saint-Anne, Quebec, Canada.

Seco, A., Ribes, J., Serralta, J. \& Ferrer, J. 2004 Biological Nutrient Removal Model No.1. Wat. Sci. Tech. 50(6), 69-78.

Serralta, J., Ferrer, J., Borrás, L. \& Seco, A. 2004 An extension of ASM2d including pH calculation. Water Res. 38(19), 4029-4038.

Takács, I., Patry, G.G. \& Nolasco, D. 1991 A dynamic model of the clarification-thickening process. Water Res. 25(10), 1263-1271.

Volcke, E. I. P. 2006 Modelling, analysis and control of a SHARON reactor in view of its coupling with an Anammox process. PhD Thesis. Faculty of Bioengineering sciences. Ghent University. p. 228, Belgium.

Van Hulle, S., Volcke, E., López, J., Donckels, B., van Loosdrecht, M.C.M. \& Vanrolleghem, P.A. 2007 Influence of temperature and $\mathrm{pH}$ on the kinetics of the Sharon nitritation process. Chem. Technol. Biotechnol. 82, 471-480.

Wett, B., Jimenez, J. A., Takács, I., Murthy, S., Bratby, J. R., Holm, N. C. \& Rönner-Holm, S. G. E. 2011 Models for nitrification process design: one or two AOB populations?. Wat. Sci. Tech. 64(3), 568-578. 